\section{Cuts and the NHS: be honest about what's possible and address inequity}

'In a dark time, the eye begins to see.' Theodore Roethke (1908-1963)

Reading McShane and Smith's BMJ article $^{1}$ on a simulated exercise on how to cut expenditure, what becomes clear is how successive reorganisations of the NHS in England have created a creature of great complexity. The Department of Health, strategic health authorities, acute trusts, medical schools, primary care trusts, community health organisations, private companies, social care, commissioning and monitoring organisations, National Institute for Health and Clinical Excellence, and the Care Quality Commission are probably the main players. It's tempting to be cynical and satirise, ${ }^{2}$ but the tragedy for patients, NHS staff, and the taxpayer is that making decisions in this melee on any rational basis is well nigh impossible. We are smaller in NHS Scotland, but alas no simpler. This may be the most financially challenging time for the NHS since its inception in 1948.

So no magic solutions but here are four suggestions.

The BMA, after discussions with all the key medical players should offer a voluntary doctors' pay freeze for 3 years for all non-training posts over a certain income level. This puts us on the front foot, saves some NHS resource, and gets us some sorely needed good media coverage.

It's a cliché but also true that financial crises are often an opportunity to address bureaucracy. In our practice (7500 patients), we have kept our staff numbers steady since 2004 over the time of the introduction of the nGMS contract despite growing demand and throughput. The NHS has not, partly because of the proliferation of organisations described above, and partly because a frequent response to poor performance at administrative and managerial level is to employ still more staff.

Start having an honest debate about what the NHS can and cannot do. On Radio 4 last week, I heard two successive features on the need for more bariatric surgery (doctor led) and more funding for services for those with multiple sclerosis (patient led). Who speaks for those unable to get an interview with John Humphrys? The usual response from medical leaders on this is that politicians can't engage with this agenda. GMC, College presidents and chairs, especially our own, need to be much more assertive on the rationing issue and lead, rather than respond to the debate both with government and in the media. If the GMC's purpose is 'to protect, promote and maintain the health and safety of the public by ensuring proper standards in the practice of medicine', ${ }^{3}$ then a renewed focus on how these resources are allocated as well as on how individual doctors use them, would be helpful for patients and the public.

Currently, patients have a 'queen' role in the NHS, at least in the rhetoric, and attention and funding for both individual patients and diseases often follow demand rather than need. This has led to persistent and unaddressed inequity in the NHS. ${ }^{4}$ If the medical profession uses the crisis to lead a national discussion on rationing and equity in the NHS, we will have achieved something.

\section{John Gillies}

\section{REFERENCES}

1. McShane M, Smith R. The NHS in the simulator. BMJ 2009; 339: b4868.

2. Oxman A, Sackett D, Chalmer I, Prescott T. A surrealistic mega-analysis of redisorganisation theories. J Roy Soc Med 2005; 98: 563-556.

3. GMC. About us. http://www.gmcuk.org/about/index.asp (accessed1 Feb 2010).

4. Watt G. The inverse care law today. Lancet 2002; 360: $252-254$.

DOI: 10.3399/bjgp10X483742

\section{Quis custodes ipsos custodiet?}

There is little doubt that cuts are on the way. It is up to us as a profession to guide and support the incumbent government. If we don't, be reassured that they will, and that 'they' in this instance will be US 'management consultants' overseen by rapacious lawyers. I propose three main areas that could stand considerable pruning for, as gardeners say, growth follows the knife. First, all private finance initiative (PFI) activity must cease; second, rational prescribing rigorously enforced; and third, we must regain control of our profession before the lawyers destroy it. To avoid medical bias, I give an example of lawyers in action: the government tried to outlaw sham marriage. The high court decided that to make these illegal would infringe the couple's civil liberties. I recently had dealings with an Independent Mental Capacity Advocate. My experience (27 years) and that of our very able nurses was as nought compared to someone who had done a weekend's course and was not with the patient (client?). The Modernising Medical Careers debacle, Medical Training Application Service, Mental Capacity Act, Postgraduate Medical Education and Training Board (PMETB), Independent Complaints Advocacy Service, and revalidation have all been overseen by lawyers. Need I say more? The GMC appears as a rabbit in the headlights in their fear of the law; the colleges even worse. Does anyone know what PMETB has achieved for us?

The first of these would be easy. PFI must be replaced by government-funded projects, unequivocally on a not-for-profit basis. The savings potential here runs to billions (in my trust alone, $£ 700$ million).

We need to move to rational rather than emotive prescribing, centralise drug budgets, and run a national formulary with a rigorous approach to pharma. For instance, prescribing statins in those whose life span is measured in months is hard to justify on any grounds, let alone 